\title{
Converting a Story from Students' Own Language in English to Increase Speaking Ability
}

\section{Ismail Ismail}

English Education Department, STKIP Muhammadiyah Enrekang, South Sulawesi-Indonesia

\section{ARTICLE INFO \\ Article History: \\ Received 20 December 2018 \\ Accepted 17 January 2019}

\section{Keywords:}

Short story, speaking skill, Indonesian EFL leaners.

\begin{abstract}
This present study required to expose the contribution of English Gossip Magazine as a resource of learning material activities to increase the students' enthusiasm in speaking skill in EFL classes. This study was carried out on two groups-experimental and control groups- each of which consists of 15 students. The students were preliminary class students of English Education Department at STKIP Muhammadiyah Enrekang, Indonesia. Before the treatment, a pretest was administered to both groups. The results of the pretest demonstrated that there was not significant difference between the control and the experimental group. Throughout the study, the experimental group was taught speaking through English Gossip Magazine materials taken from webzines, and the control group was taught through a conventional method. The result indicates that the use of the English Gossip Magazine as a resource of learning material activities could significantly contribute to increase the students, enthusiasm in speaking skill in EFL classes.
\end{abstract}

\section{INTRODUCTION}

Communication is a process which occurs delivering a message by one person to another in the form of verbal and non-verbal or verbally (directly) or indirectly, which is spoken and used by the people all over the world. Some linguists have underlined the importance of developing communicative competence, especially speaking skill in language teaching. Tompkins \& Huskisson (1995) state that the most important general goal in language instruction is to help students learn to communicate effectively with others through oral and written languages, and mastering the art of speaking is the single most important aspect of learning a second or foreign language, the success of which is measured in terms of the ability to carry out a conversation in the language.

Concerning the position of mastering the communicative competence of English based on some linguists' perspective, the national policy through the regulation of Indonesia

@Majesty Journal 2019

$\triangle$ Corresponding author:

Address : STKIP Muhammadiyah Enrekang

Email : ismail@ummaspul.ac.id
Published by STKIP Muhammadiyah Enrekang

ISSN 2567-0157 (Online) 
minister of national education no 22, 2006, reflects the importance of English in the standard of content. In this case, English is taught as a compulsory subject for senior high schools in Indonesia that is the instruction should be focused on the teaching of the four language skills. According to the standard of competence for the speaking skills, senior high school students are expected to be able to express meaningful ideas for both simple transactional (to get something done or get the information) and interpersonal (to get in touch with others for social purposes) communication to interact with people in their nearest environment (Depdiknas, 2006). The students at this level-senior high schools-are targeted to achieve the informational level that is to be able to communicate orally and in written form to find information (Depdiknas, 2006).

Speaking is like the first assessment for each learner who is studying English and each learner has to speak. This statement means an obligation, duty, task, fact, implementation, process, and it can be learning, although we still find some students are speaking little or even passive in the classroom, and it can be caused of many things include the students, the class situation, environment, teaching method, technique, approach or even from the teachers who cannot deliver their material successfully.

Dealing with the expectation of the objective in speaking skill is not easy and simple, either for the teachers or for the students. They face some difficulties in the teaching and learning of speaking. Based on the researcher's experience and observation in classroom activities, the researcher found some problems. First, students felt afraid and nervous when they wanted to speak or communicate using English in front of their classmates. Second, the students did not have any idea or initiative to speak unless he asked those questions, or when they had ideas, they did not know how to express the ideas. It was due to the lack of vocabulary, lack of understanding of grammatical patterns, and lack of practicing English speaking. Third, the students still frequently made mistakes in pronouncing the English words. It was caused by their pronunciation which was still influenced by their native language. Fourth, their problem with prosodic features such as intonation, stress, and other phonological nuances still caused misunderstanding or led to communication breakdown. Those problems made the students reluctant and unmotivated to speak (Purwatiningsih, 2015).

Teaching speaking is an interesting and challenging duty for teacher for some considerations. An EFL teacher is asked to be more creative with flexible lesson planning in teaching this skill, like selecting an appropriate technique, materials, teaching instructions, teaching aids, and time allocation which can help the students in their process to speak the language well. Nunan (1991) stated that teachers should help their students by establishing strategies to manage all forms of communication to ensure that all students have fair and equitable opportunities to develop their interpersonal speaking and listening skills, e.g. Through large and small group discussions. Dealing with the reality, the English teacher is supposed to apply more challenging techniques in teaching. The teaching will be more interesting if the teachers can create fun activities by applying some kinds of techniques that fit the students' level.

In addition, Burns \& Joyce (1999) mention that one of the most important aspects of speaking is that it always occurs within context. When we speak we are both using language to carry out various social functions and choosing forms of language which relate in a relevant way to the cultural and social context. When the teachers want to make their students communicatively competent in English as a foreign or second language, it is justifiable to say that speaking will play a large part in the overall competence. Short stories give an introduction to important themes, morals, values and look into history in the cultures of speaking countries.

The teachers' role in applying interesting methods is one of the important factors in creating a good atmosphere in the classroom activities. They should know how to improve the students 'interest and student's achievement during the class and know how to 
design materials which are easy to be understand by the students. Teachers should be able to be developed any kind of material so that learning vocabulary will not become such boring and monotonous thing. The teacher can enrich the students' speaking ability through converting a short story from own language in English.

Improving students' speaking ability, the students need to get some real life practice. Short stories are ideal resources for this real life exercise. Short stories will interpretation the students to the English vocabulary learning in a more regular format, giving a chance to see the words in context and remember them forever. Short story is one of the modern prose forms. As literary work, story becomes an interesting thing for people to read and talk. The function of story is to entertain and to enrich mental experience. Story is talking about author expression to anything about life experience concerning with human imagination.

Retelling story made the speaking activity became joyful since it could help students tell the chronological events of the story easily. Through story-retelling technique, students can demonstrate their comprehension of the story. Vale \& Feunteun (1995) stated that retelling story is a technique or an approach in teaching language. It demonstrates the value of practical tasks as social, motivational, and language teaching tools in the learning situation. It also makes students enjoy learning language.

In pedagogical theory there are strong supports for story-retelling to be used in language teaching. Cruz (2001) explains that the story-retelling as an ancient oral art can demonstrate the power of words. It artistically uses language to develop the entire critical component involved in the communication process, develops listening skill, enhances verbal expression, increases comprehension, and creates mental images. Story-retelling is an excellent means of developing speaking skills.

Story-retelling is an ancient art that is a valuable instructional tool. Teacher shares literature with their students using story retelling techniques and students tell stories too. Story-retelling is entertaining and stimulates children's imaginations. It expands their language abilities, and it helps them internalize the characteristics of stories and develop interpretations of stories (Morrow in Tompkins \& Hoskisson, 1995).

Recognizing the contribution of converting a story from students' own language in English on speaking development, we decided to implement them in a fundamental course to solve traditional learning problems and to make the learning process more efficient. Our main focus was put only on speaking skill. It is hoped that the third year students taking this course would take part in a new learning environment that make enthusiasm them to learn without limit of time and place. The findings of this study may potentially provide insights into unlocking how students learn a foreign language. The information derived from the study will be useful for the administrators in adjusting the teaching and learning process to attract the students' speaking. This study was posed by the following three research questions:

1) Is there any significant difference the students' speaking ability after the converting a short story from own language in English?

2) How does the students' respond to the converting a short story from own language in English?

\section{REVIEW LITERATURE}

\subsection{Speaking Difficulties in the Classroom}

English becomes a tool of communication worldwide. Crooks (2015) explained that based on data, the average level of female English ability is higher than that of men. He hopes that the results of this study can show the education policy, human resource quality, to the state economy level, especially welcomed the Asean Economic Community (AEC). He firmly asserted that English competence is crucial to face global competition that includes competition in various sectors. In the same occasion, Professor of International Law University of Indonesia (UI), Hikmahanto Juwana revealed, Indonesian 
people have been learning English to focus on grammar and translating but lacking practice. To know the rank of Indonesia in the Asean region, and information on the comparison of Indonesian human resources in Asean, the following authors present the Human Development Index (HDI) table:

Table 1: Asean Ratings of Human Development Index (HDI)

\begin{tabular}{clcl}
\hline No. & Country & HDI (2013) & \\
\hline $\mathbf{1}$ & Singapore & 0,901 & Very high \\
$\mathbf{2}$ & $\begin{array}{l}\text { Brunei } \\
\text { Darussalam }\end{array}$ & 0,852 & Very high \\
$\mathbf{3}$ & Malaysia & 0,773 & High \\
$\mathbf{4}$ & Thailand & 0,772 & High \\
$\mathbf{5}$ & Indonesia & $\mathbf{0 , 6 8 4}$ & Medium \\
$\mathbf{6}$ & Filipina & 0,660 & Medium \\
$\mathbf{7}$ & Vietnam & 0,638 & Medium \\
$\mathbf{8}$ & Cambodia & 0,584 & Medium \\
$\mathbf{9}$ & Laos & 0,569 & Medium \\
$\mathbf{1 0}$ & Myanmar & 0,524 & Low \\
\hline Source: & Human Development Report Resource Office, \\
United Nations Development Programme, 2 March 2013
\end{tabular}

Speaking is the active production skill and use of oral production (Widdowson, 1994). It is the capability of someone to communicate orally with others. In all of four keys language skill, Khamkhien (2010) also believed that, speaking is considered to be the most important in a second language. It is the ability that requires the process of communicative competence, pronunciation, grammar, and vocabulary improving.

\subsection{Speaking activities in the classroom}

Speaking goals to help students improve how they read in practical real-life situations and to enlarge students' range of vocabulary.

Traditional classroom speaking practice often takes the form of drills in which one person asks a question and another gives an answer. The question and the answer are structured and predictable, and often there is only one correct, preset answer. The purpose of asking and answering the question is to demonstrate the ability to ask and answer the question.

In contrast, the purpose of real communication is to accomplish a task, such as conveying a telephone message, obtaining information, or expressing an opinion. In real communication, participants must manage uncertainty about what the other person will say. Authentic communication involves an information gap; each participant has information that the other does not have. In addition, to achieve their purpose, participants may have to clarify their meaning or ask for confirmation of their own understanding.

To create classroom speaking activities that will develop communicative competence, instructors need to incorporate a purpose and an information gap and allow for multiple forms of expression. However, quantity alone will not necessarily produce competent speakers. Instructors need to combine structured output activities, which allow for error correction and increased accuracy, with communicative output activities that give students opportunities to practice language use more freely.

Formal language instruction is needed to assist our students to achieve the proficiency necessary to become successful learners in the classroom. In order to do this we need to bridge the gap between the informal language spoken at home and the formal instructional language they hear at school. To do this, students need language instruction so they can learn to speak appropriately and to listen. Oral language instruction will help students to be fluent and understand structured academic language.

Storytelling is a perfect avenue to explore when looking for ways to develop the oral language skills of second language learners in a classroom. This unit will encompass many of the techniques and strategies used to increase language skills as stated by Crevola and Vineis (Mondo 2005). For example this unit will:

1) Develop personal relationships among all the children.

2) Provide daily opportunities for language development. 
3) Create opportunities to interact regularly on a one to one basis.

4) Challenge students to talk, think, and explore their knowledge of the world.

5) Support students as they develop the language and learning strategies necessary to articulate and extend their interactions with the world.

\subsection{Storytelling}

Storytelling has long held an important role in history. People have passed down stories from generation to generation. It has served as a way to explain and understand the world. There are many different types of stories, which are told for many different purposes. Stories help explain different phenomena, cultural beliefs, attitudes, traditions, and much more. In this unit we will be focusing on folktales and traditional stories arising from the students' heritages.

Storytelling has many key values for both the individual telling the story and the people listening to the story being told. Among the values that storytelling instills in its participants as stated by Margaret Read Macdonald, in The Storytellers Start-Up Book, is that it "hones our literary and imaginative skills. We improve our ability to listen, speak, imagine, compose phrases and create stories" (Pg. 101). Macdonald continues on in her book to say that storytelling broadens our awareness of our own as well as other cultures, allows us to understand ourselves better, gives us a sense of belonging to a group and increases our vocabularies. Jack McGuire lists the benefits in his book, Creative Storytelling, by stating, "The specific educational and social benefits to storytelling from a child's point of view are numerous and well documented" (Pgs. 13-14). Some of the values McGuire touches upon are helping a child recognize patterns in language, stimulating a child's powers of creativity, providing a child with problem solving and decision making activities, strengthening a child's capacity to form objective, rational and practical applications, assisting a child to develop skills in dialogue and cooperative interpersonal behavior. It also familiarizes and introduces a child to symbols, and traditions of different cultural heritages shared among the people around them. There are tremendous gains to be made through storytelling as a strategy to increase the oral language of second language learners in particular.

Storytelling is perfect strategy to use with the students at school because it also fits in international communication magnet theme and will honor the students' cultural roots and individuality (Katherine Massa, 2008). The students at school have rich heritages and it is through this unit that they will be able to express themselves and learn about the diverse backgrounds of their fellow classmates. Stories are very important for our psychical health. We learn our mother tongue through stories. So, it is natural to learn foreign language through them as well. Teachers should try to teach their students about language, life and culture through stories.

Stories are very important for children in learning their mother tongue, and they are important in learning any foreign language as well. That is why it is good to start using stories in teaching English as soon as possible. Primary school "children enjoy listening to stories over and over again. This frequent repetition allows certain language items to be acquired while others are being overtly reinforced. Many stories contain natural repetition of key vocabulary and structures. This helps children to remember every detail, so they can gradually learn to anticipate what is about to happen next in the story. Repetition also encourages participation in the narrative". (Ellis and Brewster, 2002:2)

\subsection{Converting a story from own language}

The only way for students to learn storytelling is by doing it. If teachers can model the imaginative, creative, dramatic telling of story and allow students a chance to tell their own stories, there will be a flowering of storytelling in their class. The most important thing is that the student chooses a story that really enjoys and could imagine their selftelling. When the students have found that favourite folktale or story, the students read it 
once out loud over several times for feeling, rhythm, and tone; once to get to know the characters once to get to know the place or setting; and once to learn the order of events. Simply remember the important scenes, feelings, images, and phrases. The students should be in the story and let the students words describe what is happening in their mind. The students decide ahead of time how to use gestures, props, voices, and audience participation to make the story come alive for the students.

\section{METHODOLOGY}

\section{The Participants}

This study employed a quasiexperimental and placed in the quantitative paradigm as a collection of information is quantitative and objective statistical analysis. This study design is 'comparative-time-series' use of the control group. The use of a control group is aimed to minimize the effect of variable timing control. In learning a foreign language, the length of time spent in learning can be used as control variables that can affect the dependent variable. For this reason, each group was given a different treatment four times followed by the same set of observations for each treatment.

The participants were students of the fourth semesters of English Education Department at STKIP Enrekang Muhammadiyah. They are at the age of 19-23. The study participants were 30 students who were selected through random sampling and assigned into experimental and control groups. From the selected sample, 15 students randomly assigned to the experimental group and 15 students in the control group. Each group consisted of random or mixed levels of ability speaking ability. For this reason, they have been selected through a speaking test before the observation begins. Most students interested in learning the language through English Gossip Magazine (EGM), and they complained about the time given to practice English during regular English classes. For this reason, participants are selected, all students willingly agreed to participate in this study.

\section{Instrument and Procedure}

This study uses three types of instruments to collect data from a sample. All the instruments have undertaken a series of tests the validity of using the correlation coefficient and have met the standard criteria for concurrent validity. They are accepted as a measure used in this study and was approved at the level of concurrent validity.

\section{Speaking Test}

Speaking test was used to collect information about students' abilities before in English. The results are used to group students in the experimental group and the control to get the mix-ability groups. It is important to avoid bias in terms of intervening variables previously capabilities. All items have undertaken item analysis and testing to establish reliability in the group are not selected to participate in this study. Therefore, it is unacceptable that the most chosen item has good reliability and power of discrimination. Data obtained from the instrument analyzed and interpreted using the Statistical Package for Social Sciences (SPSS), (Setiyadi, 2006). An independent t-test was applied in order to see whether there was statistically significant difference or not between the experimental and the control group. Additionally, a paired sample t-test was used so as to compare difference within each group.

\section{Questionnaire}

The last instrument was an attitudinal questionnaire relative to mobile-assisted vocabulary exercises, investigating how the students felt about it. It consisted of ten items. The Likert five-rating scale $\quad(1=$ strongly disagree, $2=$ disagree, $3=$ neither agree nor disagree, $4=$ agree, and $5=$ strongly agree) was used for a post-study survey. The draft questionnaire items were checked for content validity by three experts in English teaching field. The items with IOC index higher than 0.6 are acceptable. In order to test the proper reliability, the questionnaire was piloted with 40 undergraduate students who were not the 
target group and calculated by using Cronbach's Alpha. According to Cronbach and Shavelson (2004), coefficient ranges in value from 0 to 1 . The higher the score, the more reliable the generated scale is. They have also indicated 0.7 to be an acceptable reliability coefficient. The coefficient value of the overall questionnaire was 0.98. After that, the questionnaire was distributed to students in the experimental group at the end of period on week 8.

\section{FINDING and DISCUSSION}

In this study, several things have been deduced. First, the subjects seem to have relatively low level of enthusiasm in learning spoken English before exposing to gossip materials taken from webzines. In the threeseries of treatment and observation, the subjects show a significant tendency to improve their level of enthusiasm from time to time. Second, the subjects in the experimental group show their enthusiasm level to be very much different from those in the control group. They outweigh their peers in the control group in terms of enthusiasm level. Third, the subjects of the study also seem to have relatively positive opinions on the use of gossip materials taken from magazines as their level of enthusiasm increases to a greater extent. Fourth, the average mean score of the students' spoken English production in all series measured by the number of turn-taking they can take over is interpreted as having less opportunity (Less Frequent) to produce spoken English. To have more understanding about the findings above, the writer discusses them using the key issues investigated in this study.

The observation results on students' enthusiasm in learning spoken English of the experimental group was taken from four series of observation. The students were given different readings from webzines (The Ultimate Hollywood Gossip Magazine: using gossip topics of the scandals between Kim Kadarshian (https://www.thehollywoodgossip.com/videos/ kim-kardashian-did-her-instagram-hint-at-splitfrom-kanye-west/), David Beckham (http://www.hellomagazine.com/tags/thebeckhams/), Paris Jackson and Kate Middleton http://www.independent.co.uk/artsentertainment/). The gossips about these Hollywood celebrities of film and sports had been modified for the purpose of this research to give greater impacts to students' curiosity and enthusiasm. For the purpose of the timeseries model, the researcher used the postobservation of every series which consisted of four series. For the control group, the researcher used materials from Scholastic Magazines with different serious topics (Entertainment; Age Discrimination; Human Right; climate change impact?). In every series of learning, there was a post-test to measure the students' time-to-time enthusiasm in using spoken English.

Therefore, this section is divided into three parts, namely (1) description of the students' enthusiasm in learning spoken English, difference of the mean score of both groups; (3) students' opinions about EGM as a learning resource in learning spoken English; and (4) volume of spoken English exposed.

\section{The Description of the Students' Enthusiasm in Learning English Speaking}

Concerning the research question, the current study was intended to investigate whether the English gossip magazine (EGM material) have an effect of the students' enthusiasm on teaching speaking of EFL students. This study was accompanied in order to consider the difference between the experimental groups taught though EGM material and the control group taught speaking material through traditional method.

\section{Comparison of pre-test scores, experimental and control groups}

An independent sample t-test was conducted in order to investigate the difference between the control group and the experimental group in terms of students' enthusiasm in learning spoken English at the beginning of the research. Table 1 demonstrates the results of independent 
Table 1. Independent sample t-test analysis for pre-test scores of experimental and control groups of enthusiasm in learning spoken English

\begin{tabular}{|l|r|r|r|r|r|r|r|r|r|}
\hline & \multicolumn{7}{|c|}{$\begin{array}{c}\text { Levene's Test } \\
\text { for Equality of } \\
\text { Variances }\end{array}$} & \multicolumn{9}{|c|}{ t-test for equality of means } \\
\hline \multicolumn{1}{|c|}{ Posttest } & $\mathrm{F}$ & Sig. & $\mathrm{t}$ & $\mathrm{df}$ & $\begin{array}{c}\text { Sig. } \\
(2- \\
\text { tailed }\end{array}$ & $\begin{array}{c}\text { Mean } \\
\text { Difference }\end{array}$ & $\begin{array}{c}\text { Std. Error } \\
\text { Difference }\end{array}$ & $\begin{array}{c}\text { 95\% Confidence Interval } \\
\text { of the Difference }\end{array}$ \\
\hline $\begin{array}{l}\text { Equal variances } \\
\text { assumed }\end{array}$ &, 107 &, 746 &,- 410 & 28 &, 685 &,- 01133 &, 02765 &,- 06798 &, 04531 \\
\hline $\begin{array}{l}\text { Equal variances } \\
\text { not assumed }\end{array}$ & & &,- 410 & 27,834 &, 685 &,- 01133 &, 02765 &, 06799 &, 04533 \\
\hline
\end{tabular}

Table 1 demonstrated that the findings produced non-significant results, to be more specific, there is not a statistically significant difference between the experimental group and the control group with regard to the pretest scores of students' enthusiasm in learning spoken English in the control and experiment groups at the beginning of the study. ( $t(28)=-.410, p=.685)$. Therefore, it is concluded that the participants in each group were equal with respect to their enthusiasm in learning spoken English competence at the beginning of the study.

\section{Comparison of pre-test, post-test scores, experimental group}

A paired-sample t-test was also conducted to compare the mean scores of pre-test and post-test of enthusiasm in learning spoken English by using English Gossip Magazine test for both control group and experimental group in order to find out whether the contribution of English Gossip Magazine are helpful in developing students' speaking learning or not. Table 2 shows that the results of pairedsamples t-test analysis for the experimental group below:

Table 2. Paired sample t-test for pre-test and post test scores of experimental group

\begin{tabular}{lllcc}
\hline & N & Mean & Std. deviation & Std. error mean \\
\hline The pre-test scores & 15 & 1,7507 &, 07860 &, 02029 \\
The post-test scores & 15 & 3,0887 &, 12501 &, 03228 \\
\hline
\end{tabular}

The findings indicated in table 2 , that there is a statistically significant difference between pre-test $(M=1.7507, S D=.07860)$ and post-test $(M=3.0887, S D=.12501)$ scores of experimental group with regard to speaking test scores. Therefore, it can be assumed that the instruction through EGM activities was found to be significantly affecting students' speaking in the current study.

\section{Comparison of pre-test, post-test scores of Control group}

Table 3 demonstrates the results of paired sample t-test analysis for the pre-test and post test scores of the control group below: 
Table 3. Paired samples t-test analysis for pre-test and post-test scores of Control Group

\begin{tabular}{lcccc}
\hline & N & Mean & Std. deviation & Std. error mean \\
\hline The pre-test scores & 15 & 1,7393 &, 07275 &, 01878 \\
The post-test scores & 15 & 1,7233 &, 06521 &, 01684 \\
\hline
\end{tabular}

As Table 3 indicates, the findings yielded to non-significant results. To be more specific, there is not a statistically significant difference between collocation pre-test $(M=1.7393$, $S D=.07275)$ and post-test $(M=1.7233, S D=$ .06521) scores of control group in terms of speaking learning. It can be concluded that the conventional instruction was found not to have a significant effect on speaking learning.

\section{Comparison of post-test scores, experimental and control groups}

Paired sample t-test analysis for the pretest and post test scores of the experimental and control group was performed in order to compare the post-test mean scores of two groups (control and experimental groups) to investigate whether there was a significant difference between these groups regarding to the type of the treatment.

Table 4. Paired samples t-test analysis for post-test scores of Experimental and Control Group

\begin{tabular}{lllccc}
\hline & Class & $\mathbf{N}$ & Mean & Std. deviation & Std. error mean \\
\hline The post-test scores & Experiment & 15 & 3,0887 &, 12501 &, 03228 \\
The post-test scores & Control & 15 & 1,7233 &, 06521 &, 01684 \\
\hline
\end{tabular}

Table 4 shows the post-test statistics of both sample groups. The mean score of enthusiasm in learning spoken English for the experimental group is 3.0887 and 1.7233 for the control group. The standard deviations of both sample groups are between -3.00 and +3.00. It means that the mean scores for individuals in the groups are in normal distribution.
Furthermore, the independent sample $\mathrm{t}$ test scores for both groups. The t-test for two different sample groups is done in two stages. The first stage is to examine whether the variance of the two groups can be regarded as identical or not. The second stage is to examine the difference of the average score of the two samples.

Table 5. Independent sample t-test analysis for the difference between the post test scores of the groups

\begin{tabular}{|l|r|r|r|r|r|r|r|r|r|}
\hline & \multicolumn{1}{|c|}{$\begin{array}{c}\text { Levene's Test } \\
\text { for Equality of } \\
\text { Variances }\end{array}$} & \multicolumn{9}{|c|}{ t-test for equality of means } \\
\hline \multicolumn{1}{|c|}{ Posttest } & $\mathrm{F}$ & Sig. & $\mathrm{t}$ & $\mathrm{df}$ & $\begin{array}{c}\text { Sig. } \\
(2- \\
\text { tailed }\end{array}$ & $\begin{array}{c}\text { Mean } \\
\text { Difference }\end{array}$ & $\begin{array}{r}\text { Std. Error } \\
\text { Difference }\end{array}$ & $\begin{array}{c}\text { 95\% Confidence Interval } \\
\text { of the Difference }\end{array}$ \\
\hline $\begin{array}{l}\text { Equal variances } \\
\text { assumed }\end{array}$ & 5,010 &, 033 & 37,505 & 28 &, 000 & 1,36533 &, 03640 & 1,29076 & 1,43990 \\
\hline $\begin{array}{l}\text { Equal variances } \\
\text { not assumed }\end{array}$ & & & 37,505 & 21,094 &, 000 & 1,36533 &, 03640 & 1,28965 & 1,44102 \\
\hline
\end{tabular}

Table 5 indicates that there is a statistically significant difference between the Speaking post test scores of control group, the score for the equal variances assumed is ( $F=5.010)$ with the probability $(p=0.000)$. Since the probability is larger than 0.05 , the two variances are 
significantly equal. The next stage is to examine if the two mean scores are significantly different or not. The mean difference of the two samples is 1.36533 (3.0887$1.7233=1.36533)$. The lower difference in $95 \%$ confidence interval is 1.29076 and the upper difference is 1.43990. It means that the difference of the speaking score of both samples is between 1.29076 and 1.44102 with the average difference is 1.36533 with the degree of freedom $\mathrm{df}=28$. It can be concluded that those who received instruction through English gossip magazine activities showed significantly higher performance in the speaking test to those who received instruction in the conventional approach.

\section{The Students' respond about EGM as a learning resource in learning spoken English}

The students in the experimental group were asked to express their respond towards EGM. Table 7 reveals the overall respond at a positive level (mean $=4.31$ ). When considering each item, it was found that the highest mean score was on no. 2 (EGM are useful sources for speaking materials, $M=4.53$ ), followed by no. 10 (EGM is highly recommended to be used as a learning resource in learning speaking and other skills, $M=4.47)$. There were three items for the third ranking. They were no. 3 (EGM helped me develop my self-confidence, Mean = 4.40), no. 8 ( $E G M$ provide freedom of learning and expressions, Mean $=4.40)$, and no. 9 (EGM in classroom speaking was like speaking in a real situation, Mean $=4.40$ ). The item that had the lowest mean score was no. 4 (EGM were fun and addictive, Mean = 3.39). However, the respond in all items were found to be positive.

Table 7. Mean, Standard Deviation and Level of Students' Respond Toward the story telling form own language in English

\begin{tabular}{clccc}
\hline No & \multicolumn{1}{c}{ Statement } & Mean & SD & Level \\
\hline 1 & Short story made me feels able to speak freely or without any pressure. & 4.27 & .59 & positive \\
\hline 2 & Short story was useful sources for speaking materials. & 4.53 & .52 & positive \\
\hline 3 & Short story helped me develop my self-confidence. & 4.40 & .74 & positive \\
\hline 4 & Short story was fun and addictive. & 3.39 & .70 & positive \\
\hline 5 & Short story allowed me constructs lots of sentences. & 4.27 & .70 & positive \\
\hline 6 & Short story increased my speaking knowledge. & 4.33 & .62 & positive \\
\hline 7 & Short story made learning vocabulary more interesting. & 4.13 & .83 & positive \\
\hline 8 & Short story provided freedom of learning and expressions. & 4.40 & .74 & positive \\
\hline 9 & Short story in classroom speaking was like speaking in a real situation. & 4.40 & .63 & positive \\
\hline \multirow{2}{*}{10} & Short story is highly recommended to be used as a learning resource in & 4.47 & .64 & positive \\
& learning speaking and other skills. & 4.31 & .09 & \\
\hline
\end{tabular}

\section{DISCUSSION}

In order to improve students speaking abilities, enthusiasm in learning arises when learners are exposed to closely related and meaningful situations from their environment, such as gossip materials. A great body of research has demonstrated that enthusiasm in speaking is one of the most important predictors of language performance, and it needs to be distinguished from other forms of enthusiasm as in some religious faith (Webster, 2008).

As Harmer (1991) reported, language serves as a tool for communication which conveys our ideas through different channels such as words, pictures, or other symbols. Communication, a function of social interaction, involves linguistic elements, intrapersonal emotional display, and external interpersonal skills. When a student's enthusiasm is high, his or her spoken English 
production may be well released without anxiety. Therefore, the issue of enthusiasm becomes more important in foreign language learning and teaching.

In this study, the major purpose was to investigate the positive impacts of gossip materials from EGM on students' enthusiasm in using spoken English. The first research question investigated the students' enthusiasm in learning spoken English through gossip topics taken from EGM. To accomplish this, the students were first observed and rated on the modified instrument of observation for enthusiasm in four series of time. The results suggest that the subjects of this study seem to increase their level of enthusiasm although at first they have relatively low level of enthusiasm in learning spoken English. Moreover, their peers in the control group have relatively low level of enthusiasm in learning spoken English as they used different materials for the treatment in four series of time. Evidence shows that students who are exposed to gossip materials taken from webzines tend to be more enthusiastic in learning to speak spoken English (Lundquist, 2008) and it supports the theory that enthusiasm in language teaching context could be attained through certain sources with certain stimuli (Donaghy, McGee, Usher and Yates, 2003; and Webster, 2005).

In essence, the findings of this research suggest that enthusiasm in speaking is a crucial factor for students to develop their confidence and to reduce their anxiety level. Gossip materials about celebrities taken from magazines or webzines are effective to improve the students' enthusiasm to a greater extent as they do not have to pay careful attention to the content of gossips. As soon as their enthusiasm is improved, they will share positive values on such materials. By the same demonstration, they will produce more spoken English through informal conversation in which they do not have to be concerned with slips or grammatical errors as spoken English is naturally full of paratactic and paralinguistic features.

Research question two attempted to reveal the students' opinions about the use of EGM as a learning resource for spoken English. The major findings of this quasi-experimental research suggested that students shared positive opinions about EGM as a learning resource in spoken English as they are more enthusiastic in doing such activities. Therefore, the second hypothesis is accepted. The results reveal that as the students have successfully improved their enthusiasm, they valued EGM positively and disregarded the negative impact of gossips.

As a matter of fact, the students in general are potential to have better achievement or better attention and respects if only the individual characteristics of the students are taken into account and the environments can be made to be more meaningful. The use of EGM can be used as an alternative to empower the students' brain to a large extent. According to the proponent of Brain-Based Learning, Jensen (1996:93), human brain is designed to find meaning. Anything can have meaning if the thing itself is important and meaningful to individuals.

These main principles can be set in several components. Here, he believes that teaching will be 'enlightened' if there is a kind of collaboration between teacher's own practice (what teachers do in the classroom) and theory (a kind of pedagogy theory from research). This kind of collaboration is gained from the teaching principles to 'intrinsic factor'. These cognitive principles envelop automatic learning, meaningful learning, and the anticipation of reward, the intrinsic motivation principle, and strategic investment. Thus, reward is one of human necessities and may give a big effect for students' success as Browns (1994) states that rewards in teaching learning process have a high impact on classroom instruction. It is an extrinsic motivation beside intrinsic motivation.

Research question three attempted to find out how much the students spoke English when they were exposed to gossip materials from EGM. The findings provide evidence that the students were more and more talkative and produced more spoken English. As the majority of the students showed their enthusiasm in speaking, they opportunity to speak more spoken English was becoming lesser. This is a normal nomenon that when they share the 
turn-taking more equally, they would have less chance to produce more utterances. Evidence supports the theory that students needed some kind of internal drive called enthusiasm served as energy enhancer, goal maintainer, curiosity gripper, interest presenter, fire igniters, fear reducer, worry dissolver, and apathy eliminator in learning spoken English (Sanders and Gosenpud, 1986; Hyken, 2008; and Poggi, 2007).

This study showed that EGM was a significant factor in improving students' enthusiasm in using spoken English. The impact of this is that such intervention designed to improve foreign language learning is strongly recommended and it is believed that this intervention may be enhanced by topics of interest to make materials more meaningful to students. Gossip materials from magazines and webzines or other resources can be modified to meet learning objectives such as learning to speak spoken English. This will, in turn, produce automatization in learning a language and will result in the improvement of learning either in quantity or in quality.

Contributions English Gossip Magazine as learning materials improves students' speaking skills. Improvement of speaking skills is seen in the participation of the enthusiasm of individual students to explain or describe the selected topic, the ability to play the role given in class meetings and presentations, the ability to ask questions, the ability to answer or respond to inquiries, and the ability to comment and argued during the discussion. There are two ways how the improvements achieved using EGM as teaching materials; The first is the procedure in the selection of topics for discussion based on the interest of the students found on the website on the internet that motivate students to be active enthusiasm in class meetings and presentations; The second is learning procedure that allows students to actively participate in class meetings and presentations. This finding implies that the EGM has the potential to increase students' speaking skills in the classroom speaking in EFL teaching at the university level.

\section{CONCLUSION}

In the present study, more than ever students are coming into school with insufficient language knowledge. Our students' oral language skills are not developed enough to support the curriculum and objectives we lecturers are forceful so hard. They require formal language instruction before they can be expected to become fluent readers, writers, and thinkers. It has been observed that storytelling as instructional material in speaking activities played a significant contribution in increasing speaking skill. In essence, the student's enthusiasm in speaking is a crucial factor to develop their confidence and to reduce their anxiety level. Short story materials about local story were effective to improve the students' enthusiasm to a greater. In addition, retelling own story form their language in English decreased the speaking anxiety of the participants. The students started to speak without the fear of making mistakes. They willingly started to take part in English speaking situation.

Helping students to speak in class $\mathrm{FL}$ is the primary responsibility of a teacher FL. In order to implement this obligation, it is necessary to inform the students that it is common to get anxious when speaking a foreign language, and they are not alone. In addition, students need to know that the teacher was waiting there to help and their courage; not to fix their mistakes or insult them. When students begin to feel safe in the classroom FL, they naturally start talking.

In conclusion, it's very crucial and urgent for teachers to improve their proficiency of using appropriate classroom English to mobilize students' learning enthusiasm. Whatever role an English teacher plays, they should use correct and accurate classroom English to stimulate students by interactive ways because effective classroom English can both motivate students' learning enthusiasm and inspire them to learn better. 
Acknowledgment

The authors would like to thank Drs. Yunus Busa, M.Si., the Chairman of STKIP Muhammadiyah Enrekang Indonesia and the students enrolled in speaking III class in 2016/2017 academic year at English Education Department of STKIP Muhammadiyah Enrekang, Indonesia, who have participated in the study.

\section{REFERENCES}

[1] Baumeister, R. F., Zhang, L., \& Vohs, K. D. (2004). Gossip as cultural learning. Review of General Psychology, 8, 111-121.

[2] Brown, G. and Yule, G. (1983a). Teaching the Spoken Language, An Approach Based on the Analysis of Conversational English. Cambridge: Cambridge University Press.

[3] Brown, H. D. (1994). Teaching by Principles. New Jersey: Prentice Hall Regent, Inc.

[4] Cambridge Advanced Learner Dictionary. (2008). CD-ROM Version.

[5] Ciprian Ceobanua \& Ștefan Boncu (2014). The challenges of the mobile technology in the young adult Education. Procedia Social and Behavioral Sciences, 142, 647 652

[6] Cronbach, L. J., \& Shavelson, R. J. (2004). My current thoughts on coefficient alpha and successor procedures. Educational and Psychological Measurement, 64 (3), 391-418.

[7] Donaghy, A., McGee, C., Ussher, B. and Yates, R. (2003). Online Teaching and Learning: A Study of Teacher Education Students' Experiences. Hamilton, NZ: Wilf Malcolm Institute of Educational Research

[8] Dunbar, R. (2004). Gossip in evolutionary perspective. Review of General Psychology, 8(2), 100-110.

[9] Ellwardt, L., Wittek, R., \& Wielers, R. (2012). Talking about the boss: Effects of generalized and interpersonal trust on workplace gossip. Group \& Organization Management, 37, 521-549. http://dx.doi.org/10.1177/105960111245 $\underline{0607}$

[10] Foster, E. (2004). Research on gossip: Taxonomy, methods, and future directions. Review of General Psychology, 8(2), 78-99.

[11] Fox, K. (2001). Evolution, Alienation and Gossip, The role of mobile telecommunication in the $21^{\text {st }}$ century. BT Cellnet, (pp. 1-15).

[12] Gossip. (2008). Cambridge advanced learner's dictionary third edition. Cambridge: Cambridge University Press.

[13] Harmer, J. (1991). The Practice of English Language Teaching. London: Longman.

[14] http://www3.telus.net/linguisticsissues Lauthenticmaterials.html on January 9, 2009.

[15] Hyken, S. (2008). Enthusiasm - It Is Contagious. Ohio: Kmalhotra Publishers.

[16] Jensen, E. (2000). BBL: The New Science of Teaching and Training. San Diego: The Brainstore

[17] Jordan, R. R (1997). English for Academic Purposes: A Guide and Resource for Teachers. Cambridge. Cambridge University Press.

[18] Katerina Georganta, Efharis Panagopoulou \& Anthony Montgomery (2014), Talking behind their backs: Negative gossip and burnout in Hospitals. Burnout Research 1: 76-81.

[19] Kilickaya, F. (2004). "Language, authentic materials and cultural content in EFL classrooms", The Internet TESL Journal, 10 (7). Retrieved from http://iteslj.org/Techniques/KilickayaAutenticMaterial.html on December 27, 2008.

[20] Kitao, K. and Kitao S.K. (2003). "Selecting and developing teaching/learning materials", In K. Kitao and S. K. Kitao. English teaching: Theory, Research and Practice (pp. 205-216). Tokyo: Eichosha.

[21] Kurland, N., \& Pelled, L. H. (2000). Passing the word: Toward a model of gossip and power in the workplace. Academy of Management Review, 25, 428-438.

[22] Lundquist, L. (2008). Learning A Spoken Second Language: How to Speak Fluently in Less Time - in An Established School or When Studying Alone. (Online). Retrieved from www.FreeEnglishNow.com on January 4, 2009. 
[23] Martinez, A. (2002). Authentic materials: An overview. Karen's Linguistic Issues. Retrieved from

[24] Meyers, A. E. (2010). Gossip talk and online community: Celebrity gossip blogs and their audiences (Dissertation). University of Massachusett - Amherst. Retrieved from http://scholarworks.umass.edu/cgi/viewc ontent.cgi?article $=1296 \&$ context=open_ac cess dissertations

[25] Meyers, E. (2009). "Can You Handle My Truth?": Authenticity and the celebrity star image. The Journal of Popular Culture, 42(5), 890-907.

[26] Michelson, G., \& Mouly, V. S. (2000). Rumour and gossip in organizations: $A$ conceptual study. Management Decision, 38, 339-346.

[27] Michelson, G., van Iterson, A., \& Waddington, K. (2010). Gossip in organizations: Contexts, consequences and controversies. Group \& Organization Management, 35, 371-390.

[28] Mitchell, W. J. T. (1995). Representation in critical terms for literary study. Retrieved from http://www.credoreference.com/entry/uc hicagols/representation

[29] Noon, M., \& Delbridge, R. (1993). News from behind my hand: Gossip in organizations. Organization Studies, 14, 23-36.

[30] Norafini Zulkurnain \& Sariit Kaur, (2001) Oral English Communication Difficulties and Coping Strategies of Diploma of Hotel Management Students at UiTM. 3L: The Southeast Asian Journal of English Language Studies, Vol 20 (3): 93-112.

[31] Nycyk, M. (2015). The power gossip and rumour have in shaping online identity and reputation: A critical discourse analysis. The Qualitative Report, 20(2), 1832.
[32] Roberts, K. H., \& O'Reilly, C. A. (1978). Organizations as communication structures: An empirical approach. Human Communication Research, 4, 283293.http://dx.doi.org/10.1111/j. 14682958.1978.tb00714.x

[33] Rosenshine, B. (1970). "Enthusiastic teaching: A research review". School Review, 78, pp.499-514

[34] Sanders, P., and Gosenpud, J. (1986). Developments in Business Simulation \& Experiential Exercises: Perceived instructor enthusiasm and student achievement. Retrieved from http://sbaweb.wayne.edu/ absel/bkl/vol1 3/13al.pdf on 24 February 2009.

[35] Sanderson, P. (1999), Using Newspapers in the Classroom. Cambridge: Cambridge University Press

[36] Setiyadi, Ag. B. (2006). Metode Penelitian untuk Pengajaran Bahasa Asing, Pendekatan Kuantitatif dan Kualitatif. (Research Methods for teaching a foreign language, quantitative and qualitative approaches). Yogyakarta: Graha Ilmu.

[37] Webster, A. S. (2005). Enthusiasm! How to Draw It and Keep It for Yourself. Ohio: Inscape Publishing.

[38] ELLIS, Gail and BREWSTER, Jean, Tell it Again!, Penguin 2002, ISBN: 0-582-447771

[39] WRIGHT, Andrew. YOU are a story absorber and a story teller. A web site for the developing language teacher [online]. 2005, accessible from WWW:

$<$ http://www.developingteachers.com/ articles tchtrainin $\mathrm{g} /$ stories andrew.htm $>$

[40] FOREST, Heather. Storytelling Lesson Plans and Activities. Story arts [online]. 2000, accessible from WWW: <http://www.storyarts.org/lessonplans/ne wstandard/inde x.html> 